\title{
The correlation of handover and the performance of nurse
}

\author{
Susanti $^{1}$, Etlidawati ${ }^{2}$ \\ ${ }^{1,2}$ Faculty of Health Science, Universitas Muhammadiyah Purwokerto
}

\begin{tabular}{l}
\hline ARTICLE INFO \\
\hline Article history: \\
Received: August 9, 2020 \\
Revised: August 20, 2020 \\
Accepted: August 30, 2020 \\
\hline
\end{tabular}

\section{Keywords:}

Handover, Nurse performance

\begin{abstract}
The means of communication between nurses and other medical teams through handover must be recorded properly. Communication dysfunction during the handover may have an effect on nursing documentation such as errors in action planning.This study aimed to determine the correlation between the implementation of handover and the performance of nurses in the inpatient room of Banyumas Hospital.This research was a descriptive analytical with a cross sectional approach research. The sample of nurses on duty in the inpatient room were 67 persons. Data were collected by using a questionnaire and the analysis of research data were completed by the Chi Square test.Most of the nurses are female totaled 43 persons (64.2\%), 65 persons are married $(97.0 \%)$ and 41 persons are civil servants $(61.2 \%)$. Most of the respondents have a DIII Nursing education (41.2\%). The average age of the nurse is 33.67 years with an average working period of 8.51 years. Most of handover are in the good category, 42 persons $(62.7 \%)$. Most of the nurses' performance are in good category totaled 49 persons $(73.1 \%)$. There is a correlation between the implementation of handover with the performance of nurses in the inpatient room of Banyumas Hospital $(\mathrm{p}=0.000)$.In conclusion better implementation of handover will improve the performance of nurses in the inpatient room of Banyumas Hospital.
\end{abstract}

This work is licensed under a Creative Commons Attribution 4.0 International License.

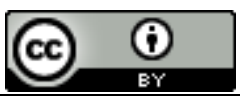

\section{Corresponding Author: \\ Susanti, Etlidawati, \\ Faculty of Health Science, Universitas Muhammadiyah Purwokerto \\ Email: lovinakirana38@gmail.com}

\section{INTRODUCTION}

Nursing documentation is an essential element in nursing services where there is a high demand for responsibility for every action that will improve patient's health status and quality of nursing services [1]. Communication tools between nurses and other medical teams through handovers carried out by nurses routinely contain information about patient's condition, nursing planning, treatment, etc. so that they must be properly recorded in the study [2]. Communication dysfunction at the time of handover carried out between nurses can have an effect on nursing documentation such as errors in action planning.

The results of research by Tamaka [3] reported that the initial data on incomplete nursing documentation reached $98.6 \%$. Winarti's research results demonstrated that nursing documentation has not been fully filled, namely the diagnosis, intervention, implementation and evaluation columns are not completely filled in on the monitoring sheet, the causes include: nurses do not comprehend the importance of the function of nursing documentation, some are indolent and think that it has no effect on their salary by writing complete documentation [4]. Research on Muslimah [5] reports that $67.4 \%$ of respondents have underperformance and $65.2 \%$ of respondents perceive a heavy workload.

Based on the interviews with the nurses about handover on May 4, 2019, data were obtained that each inpatient room conducted 2-3 times of handover / operand every day. Occasionally the nurses on duty go home earlier or arrive late so that some nurses do not follow the handover. Improper handover from the nurse on duty may affect the performance of nurses in providing nursing care to patients. According to research that performance is the result of work in quality and quantity achieved by a person in carrying out his/her duties in accordance with the responsibilities given to her/him [6]. Based on the phenomenon occurred in the inpatient room of Banyumas Hospital, the researcher 
interested in examining "the Correlation of the Handover and the Performance of Nurses in the Inpatient Room of Banyumas Hospital".

\section{RESEARCH METHOD}

This research was a descriptive analytical study with a cross sectional approach. The research was conducted in the inpatient room of Banyumas Hospital on December 10, 2019 - January 2, 2020. The population of this study were all nurses in the inpatient room of Banyumas Hospital with population of 200 nurses. Purposive sampling was employed as sampling technique by taking research samples that fit the inclusion criteria. The number of samples was calculated by using Slovin formula with the results of 67 nurses who met the inclusion criteria who were duty nurses in the Banyumas Hospital inpatient room, not on leave or attending education or training, and willing to become respondents. The variables in this study were independent variable (implementation of handover) and dependent variable (nurse performance). The instrument employed was closed questionnaire consisting of a questionnaire for the implementation of handover and the nurse performance. The data collection was carried out using questionnaire, and was given to the respondents after approving to become a respondent. The Chi Square test was employed as data analysis for this research.

\section{RESULTS AND DISCUSSIONS}

\subsection{Characteristics of Respondents}

Respondent characteristic data obtained from this study include gender, marital status, employment status, education, age and working period. The results are presented in the following table.

Table 1. Characteristics of Respondents ( $n=67)$

\begin{tabular}{lc}
\hline Characteristics & Resulth \\
\hline Gender & $24(35,8 \%)$ \\
Male & $43(64,2 \%)$ \\
Female & \\
Marital Status & $65(97,0 \%)$ \\
$\quad$ Married & $2(3,0 \%)$ \\
$\quad$ Not Married & \\
Employment Status & $41(61,2 \%)$ \\
PNS (Civil Servant) & $26(38,8 \%)$ \\
Non PNS (Non-Civil Servant) & \\
Education & $63(94,0 \%)$ \\
Diploma Nursing & $4(6,0)$ \\
Bachelor & \\
Age (Years) & 26 \\
Youngest & 47 \\
Oldest & $33,67 \pm 4,45$ \\
Mean \pm SD & \\
Working Period (Years) & 1 \\
Fastest & 20 \\
Longest & $8,51 \pm 4,09$ \\
Mean \pm SD &
\end{tabular}

Based on the results of the study, it was identified that majority of the research respondents were female; 43 female $(64.2 \%)$ and 24 male $(35.8 \%)$. Most of the respondents were married, namely 65 persons $(97.0 \%)$ and 41 $(61.2 \%)$ were civil servant. Most of the respondents had a DIII Nursing education, specifically 41 people (61.2\%). The average age of the respondents was 33.67 years with an average working period of 8.51 years.

\subsection{Bivariate Analysis}

Table 2. Analysis of the correlation between handover and nurse performance.

\begin{tabular}{llccccccc}
\hline \multirow{2}{*}{ Variable } & \multirow{2}{*}{ Category } & \multicolumn{3}{c}{ Nurse Performance } & & \multirow{2}{*}{ Total } & \multirow{2}{*}{ p-value } \\
\cline { 3 - 7 } & & \multicolumn{2}{c}{ Fairly good } & \multicolumn{2}{c}{ Good } & & & \\
\hline \multirow{3}{*}{ Handover } & & $\mathrm{f}$ & $\%$ & $\mathrm{f}$ & $\%$ & $\mathrm{n}$ & $\%$ & \\
\cline { 3 - 8 } & Fairly good & 14 & 56,0 & 11 & 44,0 & 25 & 100,0 & 0,000 \\
& Good & 4 & 9,5 & 38 & 90,5 & 42 & 100,0 & \\
\hline & Total & 18 & 26,9 & 49 & 73,1 & 67 & 100,0 & \\
\hline
\end{tabular}


Based on table 2, it was identified that according to the respondents, the handover was fairly good, most of the nurse performance was in the fairly good category (56.0\%). As for the handover according to the respondents was good, majority of the nurse performance was in the good category $(90.5 \%)$. The results of the Chi Square test obtained a $p$ value of 0.000 which was smaller than $\alpha=0.05$, meaning that there was a correlation between the implementation of handover and the performance of nurses in the inpatient room of Banyumas Hospital. Based on table 4.3, it is acknowledged that the according to the respondents, the handover is fairly good, most of the nurse performance is in the fairly good category (56.0\%). As for the handover according to the respondents is good, most of the nurse performance is in the good category (90.5\%). The results of the Chi Square test obtained a p value of 0.000 which is smaller than $\alpha=0.05$, meaning that there is a relationship between the implementation of handover and the performance of nurse in the inpatient room of Banyumas Hospital.

The results indicate that the better implementation of handover will lead to an improvement in the performance of nurses. The implementation of handover is a factor that determines the performance of nurses. According to AHHA [7], with handover, there is a continuous improvement in the quality of nursing care. Handover also serves as a support for colleagues in carrying out further nursing care actions. Handover has a positive impact on nurses, that is providing motivation, using experience and information to assist planning for the next stage of nursing care (continuous implementation of nursing care for patients), increasing communication skills between nurses, establishing a cooperative and responsible relationship between nurses, as well as following the patient's progress comprehensively. Means of Communication between nurses and other medical teams through handovers carried out by nurses routinely contain information about the patient's condition, nursing planning, treatment and others so that they must be properly recorded in the study [2]. Communication dysfunction on handover carried out between nurses may have an effect on nursing documentation such as errors in action planning. Research by Marlin [8] concludes that there is a relationship between the handover (shift operant) and the performance of the nurses in the inpatient Ward of the GMIM Pancaran Kasih Hospital.

\section{CONCLUSION}

It can be concluded that there is a correlation between the implementation of handover and the performance of nurse in the inpatient room of Banyumas Hospital where the $\mathrm{p}$ value is 0.000 which is smaller than 0.05 . So that the implementation of better handover will improve the performance of nurses in the inpatient room of Banyumas Hospital.

\section{REFERENCES}

[1] Nursalam, Pendidikan Dalam Keperawatan., Jakarta: Salemba Medika, 2015.

[2] Suryani, K. W. Karlin dan M. , "Persepsi Keluarga Terhadap Skizofrenia," Jurnal Keperawatan UNPAD, p. 124-132, 2014.

[3] R. S. Tamaka, Mulyadi dan M. Reginus , "Hubungan Beban Kerja Dengan Pendokumentasian Asuhan Keperawatan Di Instalasi Gawat Darurat Medik RSUP. PROF. DR. R.D Kandou Manado.,” 2015. [Online]. Available: https://ejournal.unsrat.ac.id/index.php/jkp/article/view/8180.

[4] W. Winarti, "Hubungan Beban Kerja Perawat dengan Pelaksanaan dan Pendokumentasian Asuhan Keperawatan di ICU RS PKU Muhammadiyah Yogyakarta.," 2015. [Online]. Available: http://digilib.unisayogya.ac.id/258/.

[5] F. Muslimah, "Hubungan Beban Kerja Dengan Kinerja Perawat Di Ruang Rawat Inap RSUD DR. Rasidin Padang.," 2015. [Online]. Available: http://repo.unand.ac.id/148/1/repository.pdf.

[6] Robbins dan Stephen, Perilaku Organisasi, Jakarta: Index, 2016.

[7] AHHA, (Australian Healthcare \& Hospitals Association), Clinical Handover System Cange, Leadership and Principles., 2009.

[8] G. Marlin, K. Rina dan H. Rivelino, "Hubungan Timbang Terima (Operan Shift) Dengan Kinerja Perawat Pelaksana Di Ruang Rawat Inap Bangsal RSU GMIM Pancaran Kasih Manado.,” ejournal unsrat, 2018. 